\title{
PROFESSIONAL TRAINING OF SPECIALISTS IN INTERNATIONAL MARKETING IN POLAND
}

\begin{abstract}
Polish experience in training specialists in international marketing in the context of globalization and integration processes has been studied. A range of theoretical resources, namely Market Entry Strategy for Poland; the articles dedicated to international marketing and economy development (W. Grzegorczyk, M. Viachevskyi, M. Urbanetst); program specifications and structures at Polish universities, namely University of Lodz and Collegium Civitas, have been analyzed. It has been defined that marketing is one of the most important activities in all types of organizations since it is a link between customers and companies in the context of global changes in business environment. The need of leading companies for their staff to be highly qualified, open for new opportunities, ready to take an initiative and comprehend the global needs and values has been justified. It has been clarified that both higher education institutions have the same strategic aims, aimed at highly professional specialists' training, the cultural-based education of youth, stimulating for critical reflection, lifelong learning, and professional development. Positive aspects in Polish experience of training future specialists in international marketing have been defined. Perspectives for further research have been considered.

Key words: international marketing, global market, globalization and integration processes, BA, professional training, study program, specialist, Polish experience.

\section{INTRODUCTION}

Due to government initiatives and reforms, as well the increase of markets' competitiveness, the Polish economy has undergone considerable changes recently. More and more investors all over the world choose Poland to invest in as its economy is regarded to be the largest among the countries that joined the EU over the last decades. Concerning the labour costs in Poland, they are lower than those in Hungary and Czech Republic. Polish specialists are considered to have a high level of professionalism due to the higher education standards, the free market development and a long-standing industrial tradition.

However, the participation of Polish companies in the international markets is still rather small (Grzegorczyk, 2014). According to KMPG, a global network aimed at providing professional audit, tax and advisory services, "inadequate market understanding and insufficient forward planning" can prevent Poland from entering a new market (Developing a Market Entry for Poland, 2001).

Consequently, it is professional marketers, in particular specializing at international marketing, who are called to assist with strategy development activities, anticipate and prepare for the opportunities and risks involved in developing international economy marketing.

Thus, the problem of international marketing specialists training becomes of the utmost importance and higher education institutions, in their turn, must prepare specialists possessing a high level of professional competences and able to create powerful marketable program of international activity on the global markets (Урбанєц, Вачевський, 2012).
\end{abstract}




\section{THE AIM OF THE STUDY}

The aim of the paper consists in 1) studying professional training programs of Bachelors in International Marketing at Polish universities; 2) justifying the organization of educational process and peculiarities of Bachelors' in International Marketing practical training; 3) defining positive aspects of Polish experience and perspectives for further researches.

\section{THEORETICAL FRAMEWORK AND RESEARCH METHODS}

For the theoretical framework of our research we have considered a range of theoretical resources, namely Market Entry Strategy for Poland developed by KMPG as perspectives for Polish international marketing entry and appropriate recommendations are presented there; the articles dedicated to international marketing and economy development in the context of globalization processes as of our importance are scientists' reflections on the topic (D. Ciesielska, M. Gorynia, W. Grzegorczyk, A. Jonas, T. Smoleń, M. Viachevskyi, M. Urbanetst, A Wożniak and others); program specifications and structures at Polish universities, at University of Lodz and Collegium Civitas in particular, since it is of scientific interest to study Polish experience in training and define positive aspects of such experience.

Studies on the problem of international marketing specialists' training in Poland have been performed with the help of such methods as theoretical analysis of literary sources and methodical documents, systematization and generalization.

\section{RESULTS}

In accordance with the aim of our paper we have to analyse peculiarities of study programs in international marketing. First of all, we would like to present peculiarities of 3year BA program in International Marketing at Collegium Civitas.

Collegium Civitas is a modern university already having earned the reputation of higher education institution offering excellent study programs.

The International Marketing program offered by the college provides students with a range of modern approaches to marketing focused on marketing creative aspects, new concepts in international theory and practice of marketing, namely advertising, customer service, market research, public relations, new product development etc; professional skills highly appreciated by international employers.

Due to dynamics of international marketing, future specialists should acknowledge the world's political, cultural, legal and business systems, identify global opportunities to be ready to face the challenges of international marketing and develop successful strategies for international marketing development. That is why the content of the program has encompassed the most important areas that are to be studied by students to obtain all the necessary knowledge, abilities and skills for professional activity. The obligatory courses are: International Marketing; International Marketing Communication; International Markets Entry Strategies; Strategic Marketing Management; International Branding, Marketing Fundamentals; Marketing Research Methods; Consumer Behaviour; Management Principles: Social Marketing; New Media Marketing; Business and Culture; Developing New Products and Consumer Innovativeness; Quantitative Methods for Business; Launching a New Venture (Collegium Civitas, 2015).

Also students have the possibility to study additional courses such as Introduction to International Relations; Theory of International Relations; Introduction to Sociology; Introduction to Politics; Introduction to Law; Philosophy; Microeconomics; Macroeconomics; Public Administration; World History 1914-1956; World History since 1956 and many others (Collegium Civitas, 2015).

So, as we can see, students are provided with strong foundation disciplines, mastering of which is aimed at achieving learning outcomes defined by the program. These learning outcomes include:

1) obtaining key competences and skills; 
2) use of extensive knowledge, theories and terminology necessary for functioning and communicating in the marketing environment;

3) understanding internationalization processes on the markets and their impact on both customers and companies;

4) analyzing and interpreting market data;

5) elaboration of recommendations for strategic plans;

6) leadership skills development;

7) development of such important skills as teamwork, speaking in public project management etc;

8) adjusting marketing strategies to changing market conditions (Collegium Civitas, 2015).

The 3-year BA program in International Marketing at University of Lodz, one of the leading higher education institutions in Poland, is designed for students with the command of English. The program comprises 600 hours dedicated to the courses in International Relations together with 1000 hours of modern marketing and business courses. The study program is practice-oriented and is focused on the international issues. International marketing management courses are based on actual case studies; therefore students are taught how to solve various business problems in the context of rapid changes in international marketing.

It should be mentioned that the best participants of the course are presented with the possibility of studying in partner universities all over the Europe that is a great opportunity for students to get acquainted with various approaches to operating in international marketing, comprehend economic and cultural diversity thus to become highly qualified and experienced in their professional sphere.

As it was mentioned before the course lasts 3 academic years divided into two terms. Specialization courses for the first term of the first academic year are Principles of Marketing; Fundamentals of Management; Social Psychology; and for the second term Fundamental of Finance; Principles of International Marketing; Basics of Effective Communication and Presentation; Intellectual Property Rights. Main courses for the first term of the first year are Economics; History of International Relations; Science of State; Physical Education and for the second term - Economics; Demography; European Integration.

Specialization courses for the third term of the second academic year are Methodology of Social Research; Introduction to International Marketing Communications; Public and non-profit marketing; for the fourth one - Introduction to Project Management; E-marketing and Social Media; Fundamentals of Human Recourses Management.

Main courses for the third term of the second year are Political Systems; Political and Economic Geography; Statistics; for the fourth one - Polish Foreign Policy; International Organizations; Fundamentals of Law; International Cultural Relations.

Specialization courses for the third academic year are Entrepreneurship and Business Planning; Sales, Export and Business Negotiations; Information Technologies in Management.

Main courses for the third year are International Economic Relations; Economic Policy; International Political Relations; International Public Law (University of Lodz, 2015).

Students also have possibilities to study one of the foreign languages, translatory studies. At the end of the course they are to complete practice, write a thesis and pass examinations.

As we can see, future specialists acquire the most advanced knowledge of international relations and international marketing to understand business processes and management tools applied in international corporations; to develop an appropriate attitude to problem-solving and team working; recognize economic and cultural diversity in management; to communicate effectively in international business environment; to be fluent in foreign languages. 
Therefore, they are ready to work in respectable international companies, organizations, public institutions, media and diplomacy at both local and global levels, scientific establishments, and research centers in Poland and abroad.

In conclusion, though both higher education institutions, Collegium Civitas and University of Lodz, apply different approaches to training specialists in international marketing, they have the same strategic aims, aimed at highly professional specialists' training, the culturalbased education of youth, stimulating for critical reflection, lifelong learning, and professional development in the context of globalization and integration processes.

\section{CONCLUSIONS}

Thus, we have studied Polish experience in training specialists in international marketing in the context of globalization and integration processes.

Having considered a range of theoretical resources, namely Market Entry Strategy for Poland; the articles dedicated to international marketing and economy development (W. Grzegorczyk, M. Viachevskyi, M. Urbanetst); program specifications and structures at Polish universities, at University of Lodz and Collegium Civitas, we have concluded that marketing is one of the most important activities in all types of organizations since it is a link between customers and companies in the context of global changes in business environment and consequently all the companies need their staff to be highly qualified, open for new opportunities, ready to take an initiative and comprehend the global needs and values.

For this matter we have studied study programs at the University of Lodz and Collegium Civitas to justify the organization of educational process and peculiarities of Bachelors' in International Marketing practical training. Despite different approaches to study and contents of study programs, both higher education institutions have the same strategic aims, aimed at highly professional specialists' training, the cultural-based education of youth, stimulating for critical reflection, lifelong learning, and professional development in the context of globalization and integration processes.

Thus, the implementation of positive aspects in Polish experience of training future specialists in international marketing will contribute to the improvement of study programs in international marketing at world universities.

Perspective for further research we consider studying learning courses dedicated to training future specialists in social media marketing.

\section{REFERENCES}

1. Collegium Civitas. (2015). International Marketing. Retrieved 3.04.2015 from: http://www.civitas.edu.pl/collegium/ofertaedukacyjna/polskoangielskie/studia-i-stopniastacjonarne-polsko-angielskie/kierunki-i-specjalnosci-studia-i-stopnia-stacjonarne-polskoangielskie/stosunki-miedzynarodowe-international-relations/marketing-miedzynarodowyinternational-marketing.

2. Grzegorczyk, W. (2014). Marketing Strategies of Polish Companies on International Markets. International Journal of Economic Practices and Theories, Volume 4, No. 5, p. 579-584.

3. KMPG International. (2011). Developing a Market Entry Strategy for Poland. Retrieved 1.04.2015 from : http://kpmg.de/docs/developing-market-entry-strategy-for-poland.pdf.

4. University of Lodz. (2015). Studies in English: International Marketing. Retrieved 3.04.2015 from : http://iso.uni.lodz.pl/study-in-english/studies-in-english.

5. Урбанєц, М., Вачевський, М. (2012). Міжнародний маркетинг глобалізації і відтворювальний механізм світового господарства [International Marketing of Globalization and the Reproducton Mechanism of World Economy]. Актуальні Проблеми Економіки [Topical Economy Problems], No. 9 (135), p. 78 -85 (in Ukrainian). 